\title{
Clinical management and outcome of histologically verified adult brainstem gliomas in Switzerland: a retrospective analysis of 21 patients
}

Hundsberger, T ; Tonder, M ; Hottinger, A ; Brügge, D ; Roelcke, U ; Putora, P M ; Stupp, R ; Weller, $\mathrm{M}$

\begin{abstract}
Because of low incidence, mixed study populations and paucity of clinical and histological data, the management of adult brainstem gliomas (BSGs) remains non-standardized. We here describe characteristics, treatment and outcome of patients with exclusively histologically confirmed adult BSGs. A retrospective chart review of adults (age $>18$ years) was conducted. BSG was defined as a glial tumor located in the midbrain, pons or medulla. Characteristics, management and outcome were analyzed. Twenty one patients (17 males; median age 41 years) were diagnosed between 2004 and 2012 by biopsy $(\mathrm{n}=15)$, partial $(\mathrm{n}=4)$ or complete resection $(\mathrm{n}=2)$. Diagnoses were glioblastoma (WHO grade IV, $\mathrm{n}=6$ ), anaplastic astrocytoma (WHO grade III, $\mathrm{n}=7$ ), diffuse astrocytoma (WHO grade II, $\mathrm{n}$ $=6$ ) and pilocytic astrocytoma (WHO grade $\mathrm{I}, \mathrm{n}=2$ ). Diffuse gliomas were mainly located in the pons and frequently showed MRI contrast enhancement. Endophytic growth was common (16 vs. 5 ). Postoperative therapy in low-grade (WHO grade I/II) and high-grade gliomas (WHO grade III/IV) consisted of radiotherapy alone (three in each group), radiochemotherapy (2 vs. 6), chemotherapy alone (0 vs. 2 ) or no postoperative therapy (3 vs. 1). Median PFS (24.1 vs. 5.8 months; log-rank, p = 0.009) and $\operatorname{mOS}(30.5$ vs. 11.5 months; log-rank, $\mathrm{p}=0.028)$ was significantly better in WHO grade II than in WHO grade III/IV tumors. Second-line therapy considerably varied. Histologically verification of adult BSGs is feasible and has an impact on postoperative treatment. Low-grade gliomas can simple be followed or treated with radiotherapy alone. Radiochemotherapy with temozolomide can safely be prescribed for high-grade gliomas without additional CNS toxicities.
\end{abstract}

DOI: https://doi.org/10.1007/s11060-014-1434-1

Posted at the Zurich Open Repository and Archive, University of Zurich

ZORA URL: https://doi.org/10.5167/uzh-95397

Journal Article

Accepted Version

Originally published at:

Hundsberger, T; Tonder, M; Hottinger, A; Brügge, D; Roelcke, U; Putora, P M; Stupp, R; Weller, M (2014). Clinical management and outcome of histologically verified adult brainstem gliomas in Switzerland: a retrospective analysis of 21 patients. Journal of Neuro-Oncology, 118(2):321-328.

DOI: https://doi.org/10.1007/s11060-014-1434-1 
Clinical management and outcome of histologically verified adult brainstem gliomas in Switzerland: a retrospective analysis of 21 patients

Thomas Hundsberger ${ }^{1,2}$, Michaela Tonder $^{3}$, Andreas Hottinger ${ }^{4}$, Detlef Brügge $^{5}$, Ulrich Roelcke $^{6}$, Paul Martin Putora ${ }^{5}$, Roger Stupp ${ }^{7}$ and Michael Weller ${ }^{3}$

${ }^{1}$ Department of Neurology, Cantonal hospital, St. Gallen, Switzerland

${ }^{2}$ Division of Hematology and Oncology, Cantonal hospital St. Gallen, Switzerland

${ }^{3}$ Department of Neurology, and Brain Tumor Center, University Hospital Zurich, Zurich, Switzerland

${ }^{4}$ Department of Clinical Neurosciences, Centre hospitalier universitaire Vaudois, Lausanne, Switzerland

${ }^{5}$ Department of Radiation Oncology, Cantonal hospital, St. Gallen, Switzerland

${ }^{6}$ Department of Neurology, Cantonal hospital, Aarau, Switzerland

${ }^{7}$ Department of Oncology, and Brain Tumor Center, University Hospital Zurich, Zurich, Switzerland

\section{Correspondence to:}

Thomas Hundsberger, MD

Department of Neurology and

Division of Hematology/Oncology

Cantonal Hospital St. Gallen

Rorschacherstr. 95

9007 St. Gallen

Switzerland

Phone: 0041714943095

Fax: $\quad 0041714942895$

Email: thomas.hundsberger@kssg.ch 


\section{Abstract}

Background: Because of low incidence, mixed study populations and paucity of clinical and histological data, the management of adult brainstem gliomas remains non-standardized. We here describe characteristics, treatment and outcome of patients with exclusively histologically confirmed adult brainstem gliomas.

Methods: A retrospective chart review of adults (> age 18 years) was conducted. Brainstem glioma was defined as a glial tumor located in the midbrain, pons or medulla. Characteristics, management and outcome were analyzed.

Results: 21 patients (17 males; median age 41 years) were diagnosed between 2004 and 2012 by biopsy $(n=15)$, partial $(n=4)$ or complete resection $(n=2)$. Diagnoses were glioblastoma (WHO grade IV, $n=6$ ), anaplastic astrocytoma (WHO grade III, $n=7$ ), diffuse astrocytoma (WHO grade $\mathrm{I}, \mathrm{n}=6$ ) and pilocytic astrocytoma (WHO grade $\mathrm{I}, \mathrm{n}=2$ ). Diffuse gliomas were mainly located in the pons and frequently showed MRI contrast enhancement. Endophytic growth was common (16 versus 5). Postoperative therapy in low-grade (WHO grade I/II) and high-grade gliomas (WHO grade III/IV) consisted of radiotherapy alone (3 in each group), radiochemotherapy (2 versus 6$)$, chemotherapy alone (0 versus 2 ) or no postoperative therapy ( 3 versus 1 ). Median PFS (24.1 versus 5.8 months; log-rank, $p=0.009$ ) and mOS (30.5 versus 11.5 months; log-rank, $p=0.028$ ) was significantly better in WHO grade II than in WHO grade III/IV tumors. Second-line therapy considerably varied.

Conclusions: Histologically verification of adult brainstem glioma is feasible and has an impact on postoperative treatment. Low-grade gliomas can simple be followed or treated with radiotherapy alone. Radiochemotherapy with temozolomide can safely be prescribed for high-grade gliomas without additional CNS toxicities.

Keywords: adults; brainstem glioma; radiochemotherapy; management; histology; 


\section{Introduction}

Brainstem gliomas (BSGs) are devastating malignancies of the central nervous system (CNS) and comprise $1-2 \%$ of adult primary brain tumors [1;2]. The median overall survival (mOS) is reported to be five years in diffuse intrinsic low-grade BSGs (LG-BSG) [1]. Highgrade BSGs (HG-BSGs) are associated with greater morbidity and mortality with a median overall survival ranging from 11 to 17 months [3-5]. In three out of four patients the tumor is localized in the pontine region, both in adults and in children [2; 5]. The midbrain and the cervico-medullary region are less commonly affected. Based on magnetic resonance imaging (MRI) four phenotypes can be defined: (1) non-enhancing, diffuse intrinsic glioma, (2) localized enhancing lesions, (3) focal tectal gliomas, and (4) other patterns [3]. Stereotactic brainstem biopsy should be the diagnostic standard of care in adults with enhancing lesions as it has the greatest impact on therapeutic decisions [1; 6]. With stereotactic biopsy a definitive diagnosis can be obtained in over $95 \%$ of the patients [7]. Despite reluctance of clinicians for biopsy and exclusive radiological diagnosis for recent years [5], the complication rate of stereotactic biopsy in experienced hands is low. Persistent disability and mortality has been reported at $1.7 \%$ and $0.9 \%$, respectively [7]. On multivariate analysis short duration of symptoms, necrosis on MRI and higher histological grade were independent negative prognostic factors [3]. Kesari and colleagues identified non-caucasian ethnicity, higher age, higher tumor grade and pontine tumor location as poor prognostic factors for survival [4]. A short time between symptom onset and diagnosis was also associated with a worse outcome of diffuse brainstem gliomas [5; 8].

Depending on severity of symptoms and tumor grade, radiotherapy has historically been the treatment of choice [2; 8]. However, irradiation doses vary among the reported series [3; 4 ; 810]. A few recent reports have administered concomitant radiochemotherapy with temozolomide [8; 9], however prospective protocols in a pediatric population were disappointing [11-14]. No agreement in the management of recurrent or progressive brainstem glioma exists.

Most recent reports were not only retrospective studies, but often analyzed a mixed patient population of both adults and children [2; 10] and contained a substantial proportion of patients without histological verification of the presumed diagnosis $[3 ; 4 ; 8]$. Only one recent case series with histologically verified tumors in patients older than 60 years was published [9]. Hence, due to the paucity of data, clinical decisions for individual patients remain challenging, and an established treatment other than radiotherapy does not exist. In this study we describe the diagnosis, clinical management and outcome in a cohort of adult patients with histologically verified LG- and HG-BSG. 


\section{Patients and methods}

We performed a retrospective review of records of adult patients (>18 years) treated for BSG at four neuro-oncology centers in Switzerland between 2004 and 2012. This study was approved by the institutional ethic committee. BSGs were defined as tumors with the main mass in the midbrain, pons or medulla [3]. Gliomas with extension to the cerebellum, the thalamus and the spinal cord were also included. Histological confirmation of the diagnosis of BSG was required to include patients in this study. BSGs of any grade were accepted. Ependymomas as a distinct clinical and molecular entity were excluded.

Clinical data comprised age at diagnosis, gender, time from first imaging to histological diagnosis, presenting signs and symptoms, location, treatment complications and neurological deterioration after surgery, written reports of cerebral MRI images (T1- and T2weight images in two planes before and after gadolinium) and written pathological reports. Results of molecular analyses were also collected. Data of first-line and follow-up therapy including degree of surgery (biopsy, resection), dose and timing of radiotherapy and chemotherapy were included. Outcome was calculated for median progression free survival (mPFS) and overall survival (mOS) based on the Kaplan-Meier estimates [15]. Survival curves were compared with the log-rank test (Mantel-Cox). PFS and OS of first-line therapy were defined from initial histological diagnosis to clinical and/or radiological progression or death.

\section{Results}

\section{Characteristics}

Twenty-one adult patients were identified (17 males) from local data basis of the participating centers. Median age at surgery was 41 years (range, 20-81). Patients with HG-BSGs were older than those with LG-BSGs (median, 48 versus 34 years, t-test; $p=0.56$ ). The median time from initial imaging to surgery was approximately 2 months in both groups. The main clinical symptoms at presentation were ataxia, oculomotor symptoms, dizziness and a sensory and/or motor hemisyndrome (Table 1). Most BSGs were located in the pons $(n=8)$. Additionally, seven BSGs extended from the pons to the midbrain or medulla (Table 1 ). Typical tectal gliomas were not present. More than half of the gliomas showed contrast enhancement on the initial MRI (13 versus 8; Table 1). Exophytic tumor growth was rare $(n=5$; Table 1). Representative MRls are shown in Fig.1.

\section{Histology and molecular biology}

Histological diagnosis was mainly achieved by biopsy ( $n=15$; Table 1$)$. A minority of patients underwent a partial resection $(n=4)$. Two pilocytic astrocytomas (WHO grade I) were macroscopically resected. In all 13 gadolinium-enhancing LG-and HG-BSGs the tumor 
samples were derived from areas of contrast enhancement. Histological diagnosis revealed glioblastoma (WHO grade IV, n=6), anaplastic astrocytoma (WHO grade III, $\mathrm{n}=7$ ) and diffuse astrocytoma (WHO grade II, $\mathrm{n}=6$ ) (Table 2). There were no oligodendrogliomas or mixed oligoastrocytic gliomas.

Molecular analysis was available in only seven cases (Table 2) mainly due to the limited tumor material and non-standardized institutional guidelines for diagnostic work-up. IDH 1/2 wild-type status was determined in one LG- and three HG-BSGs. A germline p53 mutation was found in a GBM patient suffering from a Li-Fraumeni syndrome. In one LG-BSG the p53 gene was determined as wild type. The MGMT promoter region was unmethylated in two HG-BSGs. Loss of heterozygosity of chromosome $1 p$ and $19 q$ was absent in one patient with an anaplastic astrocytoma.

\section{Therapy and outcome}

At the time of analysis (August 2013) nine patients are still alive and twelve have died from progressive disease. The median follow-up of patients being alive is 23.9 months. Neurological deterioration was observed in three patients after biopsy (patient 10,12) or gross total resection (patient 2) (Table1). In patient 2 permanent postoperative oculomotor symptoms persisted. In patient 10 and 12 pre-existing hemi-hypoesthesia and dysphagia initially worsened but partially recovered within months. Treatment and outcome after diagnosis are summarized in table 3 . Radiotherapy was given to 15 patients, temozolomide chemotherapy was administered concomitantly in 9 patients. In 2 patients with high-grade tumors chemotherapy alone was prescribed postoperatively (temozolomide). Irradiation was rejected because of previous prophylactic CNS irradiation for a hematologic neoplasia (patient 10) or to avoid clinical deterioration due to radiation-induced edema (patient 13). Focal fractionated external beam irradiation was delivered to a median dose of $54 \mathrm{~Gy}$ in conventional fractionation (range 50.4-55.8 Gy). HGG were treated to a median dose of 57.6 Gy, the doses varying widely from two patients being treated with a hypofractionated regimen with $39.75 \mathrm{~Gy}$ in 15 fractions, to patients treated in conventional fractionation (1.8 - $2 \mathrm{~Gy}$ ) from 45 to $60 \mathrm{~Gy}$. Stereotactic radiosurgery was neither prescribed for initial nor for recurrent disease. No postoperative therapy was recommended for three patients with LG-BSGs, while in one of them, rapid tumor progression did not allow further antitumor therapy.

Durable disease stabilization from 7.3 - 95.8 months was observed in five patients with LGBSGs. Three patients with HG-BSGs and one patient with a LG-BSG died of progressive disease during the initial treatment phase. Ten patients with HG-BSGs and two patients with LG-BSGs progressed. We excluded two patients with a pilocytic astrocytoma as a different disease entity in the outcome analysis (Fig. 2). Median PFS of LG-BSG was significantly better with 24.1 months compared to 5.8 months in HG-BSGs, respectively (log-rank, 
$\mathrm{p}=0.009$ ). Subsequent salvage therapy consisted of anti-VEGF treatment with bevacizumab $(n=4)$, and chemotherapy with temozolomide $(n=4)$ or lomustine $(n=2)$. One patient each underwent salvage radiotherapy or radiochemotherapy at progression after failure of initial chemotherapy. Third-line therapy in HG-BSGs consisted of bevacizumab in three patients. None of the patients underwent a second surgery or any kind of re-irradiation for progressive disease. Median OS in patients suffering from LG-BSGs $(n=6)$ and HG-BSGs $(n=13)$ was statistically different with 30.5 and 11.5 months, respectively (log-rank, $p=0.028$ ) (Table 3 , Fig. 2b). Log-rank test of mPFS and mOS of contrast enhancing versus non-contrast enhancing brainstem gliomas were statistically not significant.

\section{Discussion}

The current study represents the largest contemporary clinical investigations of histologically verified adult brainstem gliomas. Most recent studies on BSG were retrospective case series with small and heterogeneous cohorts. All but one series [9] mixed adults and children [2; 8; 16-19], various proportions of histologically non-verified brainstem lesions ranging from 10 to $72 \%[2-4 ; 8 ; 10 ; 16-19]$ or a combination of both [2; $8 ; 16-19]$. The only prospective study investigated fractionated stereotactic radiotherapy in both pediatric and adult patients, and included many patients without histological diagnosis [18]. The impact of non-malignant or even non-glial lesions (i.e. metastasis, inflammation) [6; 20], distinct molecular pathology of histone H3 alterations in pediatric BSG [21] and different prognosis in children and adults remains elusive [2; 4]. Histological verification of suspected brainstem tumors is key for appropriate subsequent therapy as the concordance of MRI imaging and histological diagnosis is low. The presumed glioma diagnosis in a cohort of 30 patients could histologically be confirmed in only $63 \%$, the others being lymphomas, metastasis or inflammatory lesions [6]. This finding underscores the importance of exact histological diagnosis before making clinical treatment decisions [20; 22]. Most series do not distinguish between low- and high-grade gliomas, although the prognosis and outcome is greatly influenced by tumor grade. In one study survival of diffuse intrinsic LG-BSG was 7.3 years compared with only 12 months in patients with high-grade BSGs [3].

In our cohort only histologically confirmed diffuse tumors of adults were included. Median age of LG-BSG was lower (34 versus 48 years) and outcome measured in terms of mPFS and mOS was as expected better than in high grade tumors (Fig $1 \mathrm{a}, \mathrm{b}$ ). Interestingly, contrast enhancement on MRI was also commonly detected in LG-BSGs. This has already been reported in a correlation study of MRI findings and histologically verified brainstem lesions and is also observed in pediatric LG-BSG [23]. Although contrast enhancement in low-grade gliomas of supratentorial localization are frequently associated with an oligodendroglial histology, oligodendrogliomas are rarely the cause for brainstem gliomas [24]. Our cohort did 
also not contain any brainstem oligodendroglioma [2-4; 8; 9]. Histological grading of BSGs might be limited due to small and non-representative specimens of the tumor for histological diagnosis. This especially accounts for biopsies. However, in our cohort all patients with contrast enhancement on the preoperative MRI tumor tissue were derived from a gadolinium enhancing area which contributes to the quality of histological diagnosis.

By its location, brainstem glioma poses particular challenges to treatment with radiotherapy. Large parts of the planning process for non-brainstem gliomas are devoted to sparing the brainstem of higher doses. This is obviously not possible in BSG. In the 1990s, dose constraints were often based on the Emami review, which at the time of publication in 1991, specified a 5-year, 5\%-rate of "necrosis/infarct" would result from 50, 53, and 60 Gy delivered to the whole, two thirds, and one third of the brainstem, respectively [25]. Several trials have subsequently defined the dose-maximum constraints to the brainstem to be in the range of 50 to 55 Gy. Newer analyses estimate that the entire brainstem may be treated to 54 Gy using conventional fractionation with limited risk of severe or permanent neurological deficits [26]. Smaller volumes of the brainstem (1-10 cc) may be irradiated to maximum doses of $59 \mathrm{~Gy}$ for dose fractions $</=2 \mathrm{~Gy}$. The risk appears to increase markedly at doses $>64$ Gy. However, there is insufficient information to determine whether there is a further volume effect [27]. The large variations of applied radiotherapy doses in our study reflect the lack of a well-established standard of care. In our series we did not observe any radiotherapy associated brainstem injury, and no increase in toxicity was seen in patients who received concomitant and adjuvant temozolomide. The current literature so far reported only common hematological toxicities in adults receiving concomitant and adjuvant temozolomide for BSG [8; 9]. This is a clinical relevant finding in the absence of a prospective trial as chemotherapy after radiation has been shown to increase the risk of CNS-radionecrosis by approximately fivefold [28]. Although feasibility has been established [29-31] and stereotactic radiotherapy is readily available in Switzerland, none of the patients in our series was treated with radiosurgery.

Various chemotherapeutics were used for salvage treatment including anti-VEGF treatment with bevacizumab. Still, efficacy of salvage chemotherapy was low with a median PFS of 2.6 months (range, 1-50 months) and a PFS after six months of $18 \%$.

Our study has several limitations due to its retrospective design and the small cohort size. Treatment recommendations for HG- and LG-BSG cannot be deduced. In the absence of standardization, the definition of clinical and radiological progression relied on the discretion of the physician. Furthermore, genetically data were scarce and do not provide any new clues for the molecular characterization of adult BSGs. However, it is the largest study reported so far distinctively investigating outcome of histologically verified adult BSG. 
In conclusion, histologically verification of brainstem gliomas is feasible, has an impact on the therapeutic strategy and avoids false diagnoses which require different treatment approaches. The benefit of a correct diagnosis has to be weight against the risk of brainstem surgery on an individual decision basis. Given the relatively good prognosis in LG-BSG achieved with no postoperative treatment or radiotherapy alone potential harmful therapies can be avoided by histologically verified tumor grading. In contrast, given the worse prognosis of HG-BSGs combined radiochemotherapy with temozolomide should be an option due to low additional toxicity albeit the lacking evidence of efficacy. Future approaches in HG-BSGs may investigate benefits from adding bevacizumab to radiochemotherapy as it may contribute to anti-tumor effects and prevent side effects from radiotherapy in higher doses in this eloquent brain region. 
1. Reyes-Botero G, Mokhtari K, Martin-Duverneuil N, Delattre JY, Laigle-Donadey F (2012) Adult brainstem gliomas. Oncologist 17: 388-397

2. Ueoka DI, Nogueira J, Campos JC, Maranhao FP, Ferman S, Lima MA (2009) Brainstem gliomas--retrospective analysis of 86 patients. J Neurol Sci 281: 20-23

3. Guillamo JS, Monjour A, Taillandier L, Devaux B, Varlet P, Haie-Meder C, Defer GL, Maison P, Mazeron JJ, Cornu P, Delattre JY (2001) Brainstem gliomas in adults: prognostic factors and classification. Brain 124: 2528-2539

4. Kesari S, Kim RS, Markos V, Drappatz J, Wen PY, Pruitt AA (2008) Prognostic factors in adult brainstem gliomas: a multicenter, retrospective analysis of 101 cases. J Neurooncol 88: $175-183$

5. Donaldson SS, Laningham F, Fisher PG (2006) Advances toward an understanding of brainstem gliomas. J Clin Oncol 24: 1266-1272

6. Dellaretti M, Touzet G, Reyns N, Dubois F, Gusmao S, Pereira JL, Blond S (2012) Correlation between magnetic resonance imaging findings and histological diagnosis of intrinsic brainstem lesions in adults. Neuro Oncol 14: 381-385

7. Kickingereder P, Willeit P, Simon T, Ruge MI (2013) Diagnostic Value and Safety of Stereotactic Biopsy for Brainstem Tumors: A Systematic Review and Meta-analysis of 1480 Cases. Neurosurgery 72: 873-882

8. Salmaggi A, Fariselli L, Milanesi I, Lamperti E, Silvani A, Bizzi A, Maccagnano E, Trevisan E, Laguzzi E, Ruda R, Boiardi A, Soffietti R (2008) Natural history and management of brainstem gliomas in adults. A retrospective Italian study. J Neurol 255: 171-177

9. Babu R, Kranz PG, Karikari IO, Friedman AH, Adamson C (2013) Clinical characteristics and treatment of malignant brainstem gliomas in elderly patients. J Clin Neurosci 20: 13821386

10. Landolfi JC, Thaler HT, DeAngelis LM (1998) Adult brainstem gliomas. Neurology 51: 1136-1139

11. Chiang KL, Chang KP, Lee YY, Huang PI, Hsu TR, Chen YW, Chang FC, Wong TT (2010) Role of temozolomide in the treatment of newly diagnosed diffuse brainstem glioma in children: experience at a single institution. Childs Nerv Syst 26: 1035-1041

12. Chassot A, Canale S, Varlet $P$, Puget $S$, Roujeau T, Negretti L, Dhermain F, Rialland X, Raquin MA, Grill J, Dufour C (2012) Radiotherapy with concurrent and adjuvant temozolomide in children with newly diagnosed diffuse intrinsic pontine glioma. J Neurooncol 106: 399-407

13. Cohen KJ, Heideman RL, Zhou T, Holmes EJ, Lavey RS, Bouffet E, Pollack IF (2011) Temozolomide in the treatment of children with newly diagnosed diffuse intrinsic pontine gliomas: a report from the Children's Oncology Group. Neuro Oncol 13: 410-416

14. Jalali R, Raut N, Arora B, Gupta T, Dutta D, Munshi A, Sarin R, Kurkure P (2010) Prospective evaluation of radiotherapy with concurrent and adjuvant temozolomide in children with newly diagnosed diffuse intrinsic pontine glioma. Int $\mathbf{J}$ Radiat Oncol Biol Phys 77: 113-118 
15. Kaplan E, Meier P (1958) Nonparametric estimation from incomplete observations. J Am Stat Assoc 53: 457-481

16. Rosenthal MA, Ashley DM, Drummond KJ, Dally M, Murphy M, Cher L, Thursfield V, Giles GG (2008) Brain stem gliomas: patterns of care in Victoria from 1998-2000. J Clin Neurosci 15: 237-240

17. Schild SE, Stafford SL, Brown PD, Wood CP, Scheithauer BW, Schomberg PJ, Wong WW, Lyons MK, Shaw EG (1998) The results of radiotherapy for brainstem tumors. J Neurooncol 40: 171-177

18. Schulz-Ertner D, Debus J, Lohr F, Frank C, Hoss A, Wannenmacher M (2000) Fractionated stereotactic conformal radiation therapy of brain stem gliomas: outcome and prognostic factors. Radiother Oncol 57: 215-223

19. Tokuriki Y, Handa H, Yamashita J, Okumura T, Paine JT (1986) Brainstem glioma: an analysis of 85 cases. Acta Neurochir (Wien ) 79: 67-73

20. Massager N, David P, Goldman S, Pirotte B, Wikler D, Salmon I, Nagy N, Brotchi J, Levivier M (2000) Combined magnetic resonance imaging- and positron emission tomography-guided stereotactic biopsy in brainstem mass lesions: diagnostic yield in a series of 30 patients. J Neurosurg 93: 951-957

21. Wu G, Broniscer A, McEachron TA, Lu C, Paugh BS, Becksfort J, Qu C, Ding L, Huether R, Parker M, Zhang J, Gajjar A, Dyer MA, Mullighan CG, Gilbertson RJ, Mardis ER, Wilson RK, Downing JR, Ellison DW, Zhang J, Baker SJ (2012) Somatic histone H3 alterations in pediatric diffuse intrinsic pontine gliomas and non-brainstem glioblastomas. Nat Genet 44: 251-253

22. Laigle-Donadey F, Doz F, Delattre JY (2008) Brainstem gliomas in children and adults. Curr Opin Oncol 20: 662-667

23. Ahmed KA, Laack NN, Eckel LJ, Orme NM, Wetjen NM (2013) Histologically Proven, Low-grade Brainstem Gliomas in Children: 30-Year Experience With Long-term Follow-up at Mayo Clinic. Am J Clin Oncol epub ahead of print

24. Khalid L, Carone M, Dumrongpisutikul N, Intrapiromkul J, Bonekamp D, Barker PB, Yousem DM (2012) Imaging Characteristics of Oligodendrogliomas That Predict Grade. American Journal of Neuroradiology 33: 852-857

25. Emami B, Lyman J, Brown A, Coia L, Goitein M, Munzenrider JE, Shank B, Solin LJ, Wesson M (1991) Tolerance of normal tissue to therapeutic irradiation. Int J Radiat Oncol Biol Phys 21: 109-122

26. Merchant TE, Chitti RM, Li C, Xiong X, Sanford RA, Khan RB (2010) Factors associated with neurological recovery of brainstem function following postoperative conformal radiation therapy for infratentorial ependymoma. Int J Radiat Oncol Biol Phys 76: 496-503

27. Mayo C, Yorke E, Merchant TE (2010) Radiation associated brainstem injury. Int J Radiat Oncol Biol Phys 76: S36-S41

28. Ruben JD, Dally M, Bailey M, Smith R, McLean CA, Fedele P (2006) Cerebral radiation necrosis: incidence, outcomes, and risk factors with emphasis on radiation parameters and chemotherapy

1. Int J Radiat Oncol Biol Phys 65: 499-508 
29. Kased N, Huang K, Nakamura JL, Sahgal A, Larson DA, McDermott MW, Sneed PK (2008) Gamma knife radiosurgery for brainstem metastases: the UCSF experience. J Neurooncol 86: 195-205

30. Sharma MS, Kondziolka D, Khan A, Kano H, Niranjan A, Flickinger JC, Lunsford LD (2008) Radiation tolerance limits of the brainstem. Neurosurgery 63: 728-732

31. Schulz-Ertner D, Debus J, Lohr F, Frank C, Hoss A, Wannenmacher M (2000) Fractionated stereotactic conformal radiation therapy of brain stem gliomas: outcome and prognostic factors. Radiother Oncol 57: 215-223 


\section{Acknowledgements:}

We thank Johannes Weber for providing the MRI images and all local physicians from the different centers for providing clinical data for the study.

Table 1

Individual patient and imaging characteristics (ID 1-8, low-grade gliomas; ID 9-21, high-grade gliomas)

\section{Table 2}

Results of histological and molecular investigations

\section{Table 3}

Therapy and outcome

\section{Fig 1}

Transversal MRI scans of a medullary low-grade brainstem glioma (a, T1-weighted, T1weighted + Gadolinium; T2-weighted) and a ponto-medullary glioblastoma of the brainstem (b, T1-weighted, T1-weighted + Gadolinium; T2-weighted). The glioma is indicated with a white arrow

\section{Fig 2}

Kaplan-Meier estimates of PFS (a) and overall survival (b) for low-grade (LG-BSG, blue line)) and high-grade brainstem gliomas (HG-BSG, green line) $(n=19)$. Pilocytic astrocytomas $(n=2)$ were excluded from outcome analysis.

\section{Ethical standards}

This study was approved by the institutional ethics committee (EKSG 13/093).

\section{Disclosure}

$\mathrm{TH}, \mathrm{UR}$ and $\mathrm{AH}$ received honaria for lectures or advisory board participation from Roche and MSD. MW has received research grants from Bayer, ISARNA Therapeutics, MSD, Merck Serono and Roche and honoraria for lectures or advisory board participation from ISARNA Therapeutics, Magforce, MSD, Merck Serono, Pfizer, Roche and Teva. DB, MT, RS and PMP declare no conflict of interest. 
Fig 1
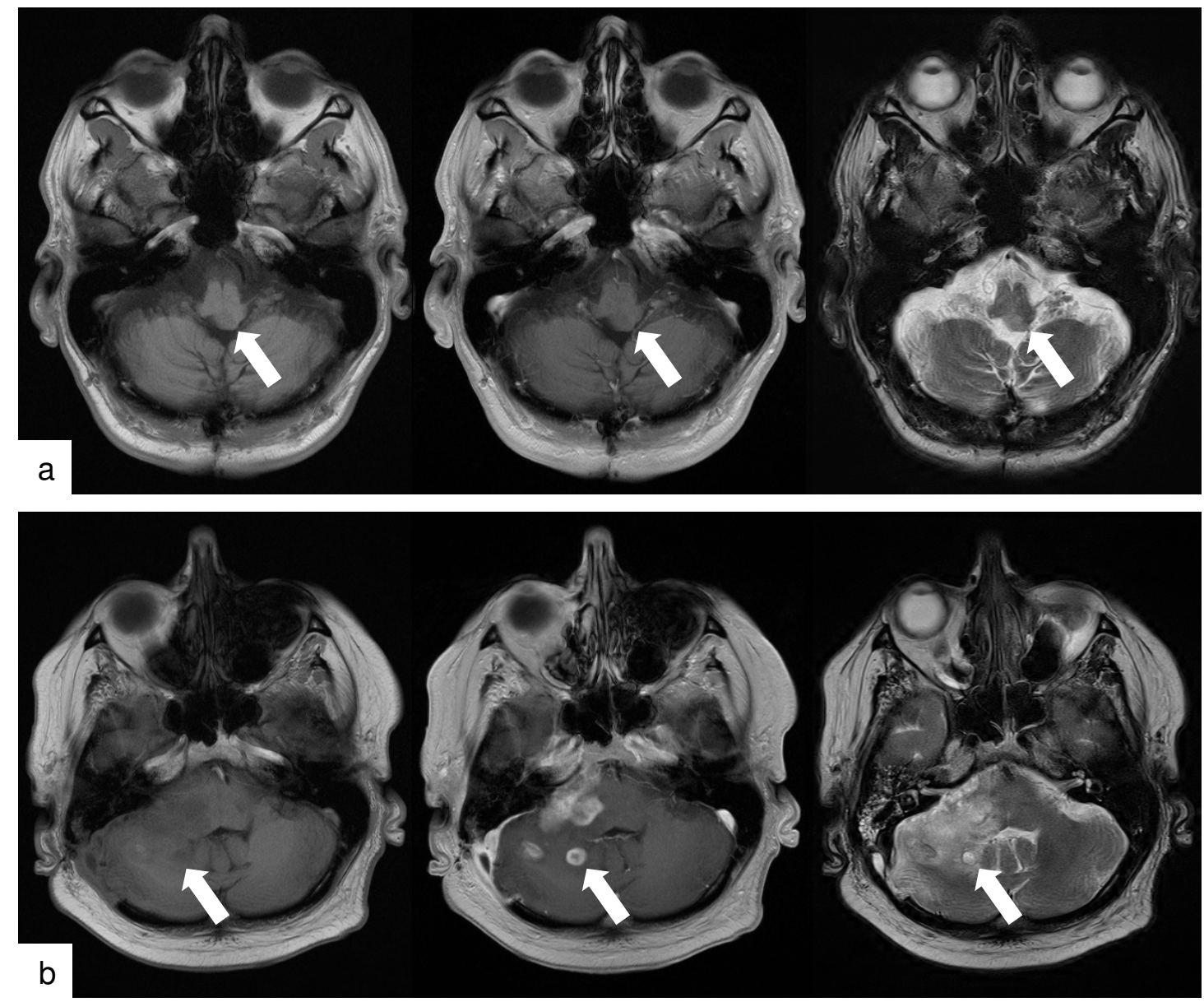
Fig 2

a.

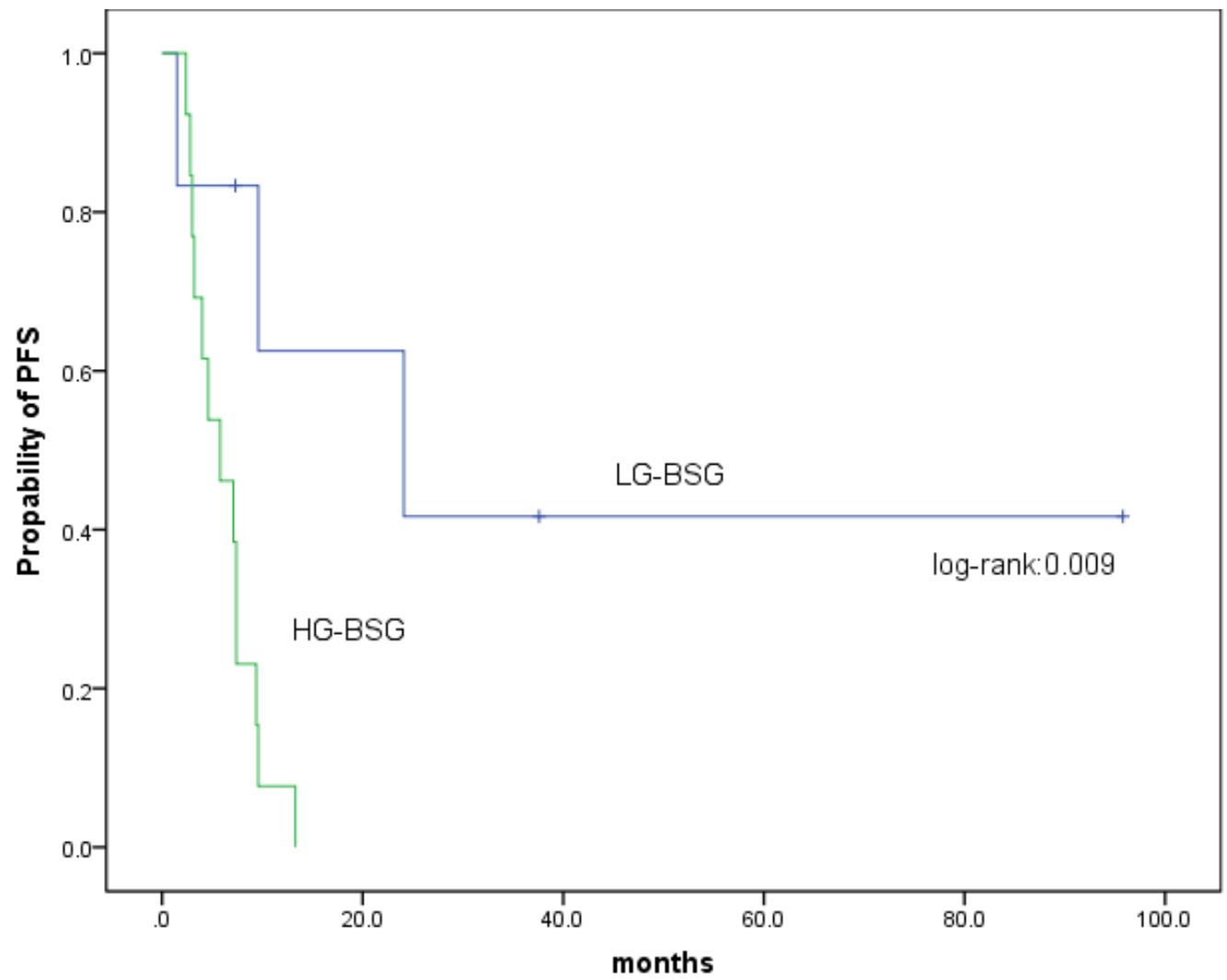

b.

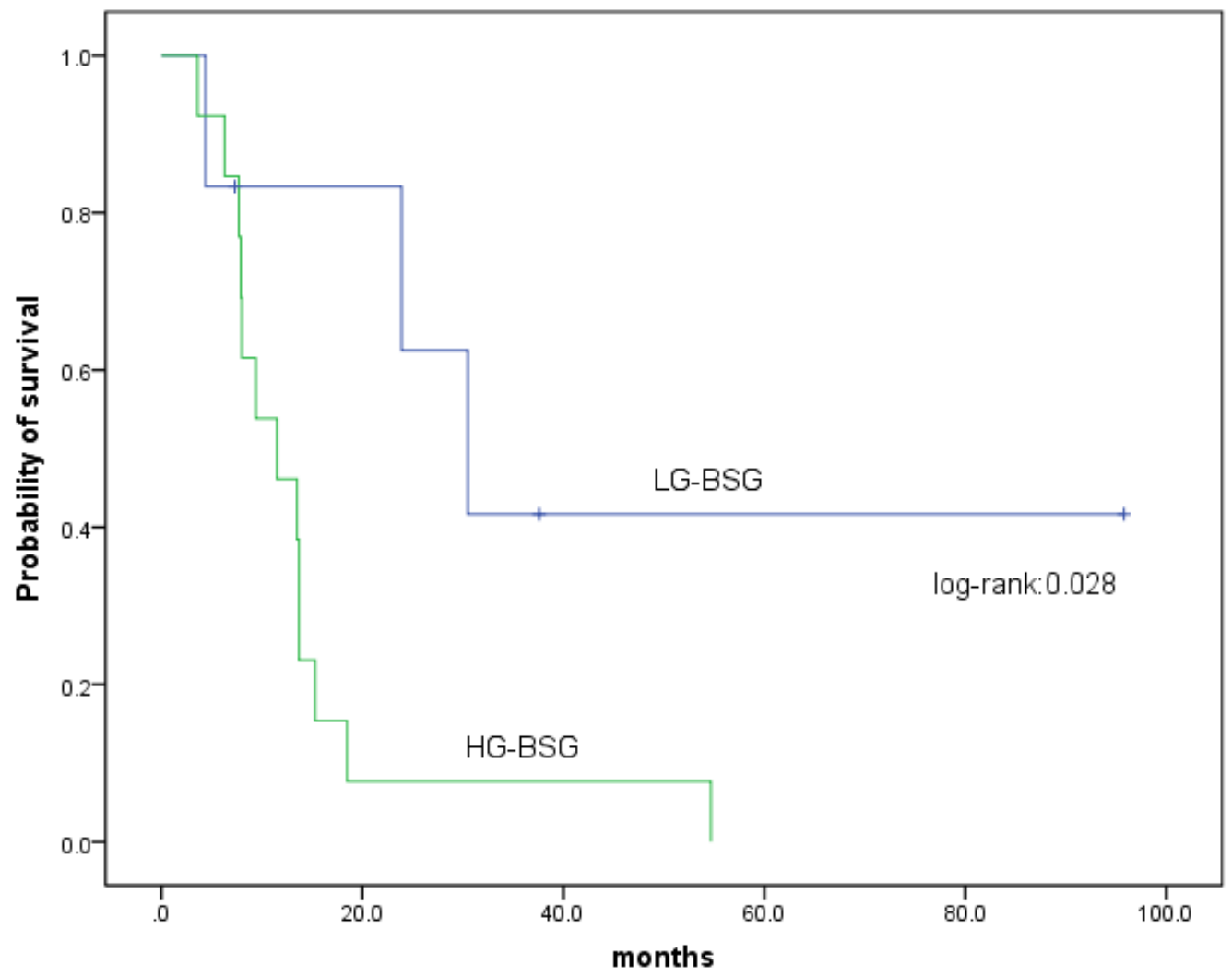


Table 1:

\begin{tabular}{|c|c|c|c|c|c|c|c|c|c|}
\hline ID & $\begin{array}{c}\text { age } \\
\text { [years] }\end{array}$ & $\begin{array}{l}\text { main } \\
\text { location }\end{array}$ & $\begin{array}{l}\text { initial } \\
\text { symptoms }\end{array}$ & $\begin{array}{l}\text { exophytic } \\
\text { growth }\end{array}$ & $\begin{array}{l}\text { type of } \\
\text { surgery }\end{array}$ & $\begin{array}{l}\text { location of } \\
\text { surgery }\end{array}$ & CE & $\begin{array}{c}\text { specimen } \\
\text { of } \\
\text { CE area }\end{array}$ & $\begin{array}{l}\text { postoperative } \\
\text { deterioration }\end{array}$ \\
\hline 1 & 29 & pons & $\begin{array}{l}\text { headache, } \\
\text { dizziness }\end{array}$ & + & $\begin{array}{l}\text { gross total } \\
\text { resection }\end{array}$ & pons & + & + & no \\
\hline 2 & 39 & $\begin{array}{l}\text { midbrain, } \\
\text { pons }\end{array}$ & $\begin{array}{c}\text { sensorimotor } \\
\text { hemisyndrome }\end{array}$ & - & $\begin{array}{l}\text { gross total } \\
\text { resection }\end{array}$ & $\begin{array}{c}\text { pedunculus } \\
\text { cerebri }\end{array}$ & + & + & yes \\
\hline 3 & 48 & $\begin{array}{l}\text { midbrain, } \\
\text { pons }\end{array}$ & $\begin{array}{c}\text { hiccup, } \\
\text { dizziness }\end{array}$ & - & $\begin{array}{l}\text { partial } \\
\text { resection }\end{array}$ & $\begin{array}{l}\text { floor of the } \\
\text { 4th ventricle }\end{array}$ & - & $\mathrm{n} / \mathrm{a}$ & no \\
\hline 4 & 57 & medulla & $\begin{array}{l}\text { diplopia, } \\
\text { dizziness }\end{array}$ & - & biopsy & $\begin{array}{c}\text { nuclei } \\
\text { olivaris }\end{array}$ & + & + & no \\
\hline 5 & 28 & pons & $\begin{array}{c}\text { diplopia } \\
\text { headache }\end{array}$ & - & biopsy & pons & - & $\mathrm{n} / \mathrm{a}$ & no \\
\hline 6 & 71 & $\begin{array}{l}\text { midbrain, pons, } \\
\text { medulla }\end{array}$ & $\begin{array}{l}\text { ataxia, } \\
\text { diplopia }\end{array}$ & - & biopsy & pons & - & $\mathrm{n} / \mathrm{a}$ & no \\
\hline 7 & 25 & pons & headache & - & biopsy & $\begin{array}{l}\text { brachium } \\
\text { pontis }\end{array}$ & + & + & no \\
\hline 8 & 24 & midbrain & diplopia & - & biopsy & thalamus & - & $n / a$ & no \\
\hline 9 & 52 & $\begin{array}{l}\text { midbrain, } \\
\text { pons }\end{array}$ & $\begin{array}{l}\text { ataxia, } \\
\text { nausea }\end{array}$ & - & biopsy & pons & + & + & no \\
\hline 10 & 41 & pons & $\begin{array}{l}\text { Hemi-hypoesthesia, } \\
\text { pain }\end{array}$ & - & biopsy & pons & - & $\mathrm{n} / \mathrm{a}$ & yes \\
\hline 11 & 48 & $\begin{array}{l}\text { pons, } \\
\text { medulla }\end{array}$ & $\begin{array}{l}\text { hemisyndrome, } \\
\text { tremor }\end{array}$ & + & biopsy & pons & - & $\mathrm{n} / \mathrm{a}$ & no \\
\hline 12 & 40 & midbrain & $\begin{array}{c}\text { abducent nerve palsy, } \\
\text { dysphagia }\end{array}$ & + & biopsy & pons & + & + & yes \\
\hline
\end{tabular}




\begin{tabular}{|c|c|c|c|c|c|c|c|c|c|}
\hline 13 & 27 & pons & $\begin{array}{l}\text { trigeminal symptoms, } \\
\text { double vision, dysphagia }\end{array}$ & - & biopsy & pons & - & $\mathrm{n} / \mathrm{a}$ & no \\
\hline 14 & 48 & pons & hydrocephalus occlusus & - & biopsy & obex & + & + & no \\
\hline 15 & 23 & midbrain & $\begin{array}{l}\text { ataxia, } \\
\text { fatigue }\end{array}$ & - & biopsy & $\begin{array}{c}\text { cerebellar } \\
\text { hemisphere }\end{array}$ & - & $\mathrm{n} / \mathrm{a}$ & no \\
\hline 16 & 33 & pons & $\begin{array}{c}\text { ataxia, } \\
\text { double vision }\end{array}$ & - & biopsy & thalamus & + & + & no \\
\hline 17 & 55 & medulla & $\begin{array}{l}\text { trigeminal palsy, } \\
\text { ataxia }\end{array}$ & - & biopsy & $\begin{array}{l}\text { cerebellar } \\
\text { hemisphere }\end{array}$ & + & + & no \\
\hline 18 & 20 & pons & $\begin{array}{c}\text { ataxia, } \\
\text { dysarthria }\end{array}$ & - & $\begin{array}{c}\text { partial } \\
\text { resection }\end{array}$ & $\begin{array}{c}\text { cerebellar } \\
\text { hemisphere }\end{array}$ & + & + & no \\
\hline 19 & 81 & $\begin{array}{l}\text { midbrain, } \\
\text { pons }\end{array}$ & $\begin{array}{l}\text { trigeminal palsy, } \\
\text { ataxia }\end{array}$ & + & $\begin{array}{c}\text { partial } \\
\text { resection }\end{array}$ & pons & + & + & no \\
\hline 20 & 53 & midbrain & hemiparesis & - & biopsy & pons & + & + & no \\
\hline 21 & 67 & $\begin{array}{l}\text { midbrain, } \\
\text { pons }\end{array}$ & $\begin{array}{c}\text { hemiparesis, } \\
\text { headaches }\end{array}$ & + & $\begin{array}{c}\text { partial } \\
\text { resection }\end{array}$ & pons & + & + & no \\
\hline
\end{tabular}

Abbreviations: ID, identification; n/a, not applicable; CE, contrast enhancement 
Table 2:

\begin{tabular}{|c|c|c|c|c|c|c|}
\hline ID & $\begin{array}{c}\text { WHO } \\
\text { grade }\end{array}$ & histology & $\begin{array}{c}\text { MGMT } \\
\text { promoter } \\
\text { methylation }\end{array}$ & $\begin{array}{c}\text { IDH 1/2 } \\
\text { mutation }\end{array}$ & $\begin{array}{c}\text { p53 } \\
\text { mutation }\end{array}$ & $\begin{array}{c}\text { 1p/19q } \\
\text { co-deletion }\end{array}$ \\
\hline 1 & I & PA & n/a & $\mathrm{n} / \mathrm{a}$ & $\mathrm{n} / \mathrm{a}$ & $\mathrm{n} / \mathrm{a}$ \\
\hline 2 & I & PA & $\mathrm{n} / \mathrm{a}$ & $\mathrm{n} / \mathrm{a}$ & $\mathrm{n} / \mathrm{a}$ & $\mathrm{n} / \mathrm{a}$ \\
\hline 3 & II & A & $\mathrm{n} / \mathrm{a}$ & $\mathrm{n} / \mathrm{a}$ & $\mathrm{n} / \mathrm{a}$ & $\mathrm{n} / \mathrm{a}$ \\
\hline 4 & II & A & $\mathrm{n} / \mathrm{a}$ & $\mathrm{n} / \mathrm{a}$ & $\mathrm{n} / \mathrm{a}$ & $\mathrm{n} / \mathrm{a}$ \\
\hline 5 & II & A & $\mathrm{n} / \mathrm{a}$ & $\mathrm{wt} / \mathrm{wt}$ & $\mathrm{wt}$ & $\mathrm{n} / \mathrm{a}$ \\
\hline 6 & II & A & $\mathrm{n} / \mathrm{a}$ & $\mathrm{n} / \mathrm{a}$ & $\mathrm{n} / \mathrm{a}$ & $\mathrm{n} / \mathrm{a}$ \\
\hline 7 & II & A & $\mathrm{n} / \mathrm{a}$ & $\mathrm{n} / \mathrm{a}$ & $\mathrm{n} / \mathrm{a}$ & $\mathrm{n} / \mathrm{a}$ \\
\hline 8 & II & A & $\mathrm{n} / \mathrm{a}$ & $\mathrm{n} / \mathrm{a}$ & $\mathrm{n} / \mathrm{a}$ & $\mathrm{n} / \mathrm{a}$ \\
\hline 9 & III & AA & $\mathrm{n} / \mathrm{a}$ & $\mathrm{n} / \mathrm{a}$ & $\mathrm{n} / \mathrm{a}$ & $\mathrm{n} / \mathrm{a}$ \\
\hline 10 & III & AA & $\mathrm{n} / \mathrm{a}$ & $\mathrm{wt} / \mathrm{wt}$ & $\mathrm{n} / \mathrm{a}$ & $\mathrm{n} / \mathrm{a}$ \\
\hline 11 & III & AA & $\mathrm{n} / \mathrm{a}$ & $\mathrm{n} / \mathrm{a}$ & $\mathrm{n} / \mathrm{a}$ & $\mathrm{intact}$ \\
\hline 12 & III & AA & negative & $\mathrm{n} / \mathrm{a}$ & $\mathrm{n} / \mathrm{a}$ & $\mathrm{n} / \mathrm{a}$ \\
\hline
\end{tabular}




\begin{tabular}{|c|c|c|c|c|c|c|}
\hline 13 & III & AA & $n / a$ & $\mathrm{wt} / \mathrm{wt}$ & mutant & $n / a$ \\
\hline 14 & III & $A A$ & $\mathrm{n} / \mathrm{a}$ & $\mathrm{n} / \mathrm{a}$ & $\mathrm{n} / \mathrm{a}$ & $\mathrm{n} / \mathrm{a}$ \\
\hline 15 & III & $A A$ & $\mathrm{n} / \mathrm{a}$ & $\mathrm{n} / \mathrm{a}$ & $\mathrm{n} / \mathrm{a}$ & $\mathrm{n} / \mathrm{a}$ \\
\hline 16 & IV & GBM & $\mathrm{n} / \mathrm{a}$ & $\mathrm{n} / \mathrm{a}$ & $\mathrm{n} / \mathrm{a}$ & $\mathrm{n} / \mathrm{a}$ \\
\hline 17 & IV & GBM & $\mathrm{n} / \mathrm{a}$ & $\mathrm{n} / \mathrm{a}$ & $\mathrm{n} / \mathrm{a}$ & $\mathrm{n} / \mathrm{a}$ \\
\hline 18 & IV & GBM & $\mathrm{n} / \mathrm{a}$ & $\mathrm{n} / \mathrm{a}$ & mutant & $\mathrm{n} / \mathrm{a}$ \\
\hline 19 & IV & GBM & $\mathrm{n} / \mathrm{a}$ & $\mathrm{n} / \mathrm{a}$ & $\mathrm{n} / \mathrm{a}$ & $\mathrm{n} / \mathrm{a}$ \\
\hline 20 & IV & GBM & $\mathrm{n} / \mathrm{a}$ & $\mathrm{n} / \mathrm{a}$ & $\mathrm{n} / \mathrm{a}$ & $\mathrm{n} / \mathrm{a}$ \\
\hline 21 & IV & GBM & negative & wt/wt & $n / a$ & $\mathrm{n} / \mathrm{a}$ \\
\hline
\end{tabular}

Abbreviations: ID, identification; n/a, not applicable; wt, wild type, PA, pilocytic astrocytoma; A, diffuse astrocytoma; AA, anaplastic astrocytoma, GBM, glioblastoma multiforme 
Table 3: Therapy and outcome

\begin{tabular}{lcc}
\hline & $\begin{array}{c}\text { LG-BSG } \\
\mathrm{n}=8\end{array}$ & $\begin{array}{c}\text { HG-BSG } \\
\mathrm{n}=13\end{array}$ \\
\hline $\begin{array}{l}\text { postoperative therapy } \\
\text { no treatment }\end{array}$ & 3 & 1 \\
$\begin{array}{l}\text { radiotherapy } \\
\text { radiochemotherapy (with temozolomide) }\end{array}$ & 3 & 3 \\
$\quad$ chemotherapy & 2 & 7 \\
\hline median PFS after postoperative treatment $^{1}$ & 0 & 2 \\
months $^{\text {(range) }}$ & 24.1 & $(2.4-13.3)$ \\
\hline median OS $^{1}$ & $(1.5-95.8)$ & 11.5 \\
months & & $(3.6-54.7)$ \\
(range) & 30.5 & \\
\hline
\end{tabular}

${ }^{1}$ two patients with pilocytic astrocytomas were excluded from the analysis 